\title{
A courtship but not much of a marriage. Lévi- Strauss and British Americanist anthropology
}

\section{Stephen Hugh-Jones}

\section{OpenEdition}

\section{Journals}

Édition électronique

URL : https://journals.openedition.org/jsa/10547

DOI : 10.4000/jsa. 10547

ISSN : 1957-7842

Éditeur

Société des américanistes

\section{Édition imprimée}

Date de publication : 20 décembre 2008

Pagination : 17-27

ISSN : 0037-9174

\section{Référence électronique}

Stephen Hugh-Jones, « A courtship but not much of a marriage. Lévi-Strauss and British

Americanist anthropology », Journal de la Société des américanistes [En ligne], 94-2 | 2008, mis en ligne

le 10 décembre 2013, consulté le 03 septembre 2022. URL : http://journals.openedition.org/jsa/

10547 ; DOI : https://doi.org/10.4000/jsa. 10547 


\title{
A COURTSHIP BUT NOT MUCH OF A MARRIAGE. LÉVI-STRAUSS AND BRITISH AMERICANIST ANTHROPOLOGY
}

\author{
Stephen HUGH-JONES *
}

To begin with I should say how honoured I am to be able to render homage to Lévi-Strauss, who I personally consider to be not only the greatest living anthropologist, but also the greatest anthropologist, full stop. So it's a great pleasure to be allowed to say some words about him. However, I'm afraid I'm the bringer of not particularly good news in that what I want to say to you is that my colleagues - my British colleagues - probably should have rendered rather more homage than they have done.

I want first to show you a virtual slide. This is a picture of a cartoon, which has unfortunately been destroyed but which Alfred Gell passed to me in 1965. Alfred Gell, my alas dead colleague, was an excellent draftsman and, in the middle of a lecture by Leach, he drew a cartoon which he entitled « The Matchmaker ». The cartoon showed France and England separated by the Channel. On the French side was a rather reluctant looking bride, called Lévi-Strauss [laughs] and on the English side were a series of functionalists - Fortes, Radcliffe-Brown, Goody and others - who were supposed to be the grooms. Leach was in the middle of the Channel trying to introduce the grooms to the bride. But the reluctant grooms were all holding up their hands in horror like this [laughs]. So now you know where my title comes from.

It is usually assumed, I think, that, at least relative to the American tradition, Britain and France share a common structuralist tradition. To simplify matters one might say that the US tradition is characterized, on the one hand, by cultural ecology and, on the other hand, by various kinds of linguistic tradition: ethnosemantics (which some people have also called "structuralism »), discourse studies etc., and also "Culture and Personality ». All that may be relatively or comparatively true, but what I want to say is that adherence to what I'm going to call " generic, vulgar structuralism » - the accepted canon of exchange theory,

\footnotetext{
* King's College, Cambridge, CB2 1ST [sh116@cam.ac.uk].

Journal de la Société des Américanistes, 2008, 94-2, pp. 17-27. OSociété des Américanistes.
} 
alliance theory, binary oppositions, reference to myths and various other things -, is not at all the same thing as direct influence by, or engagement with, the work of Lévi-Strauss. I think it could be said that all British Americanists share this kind of generic structuralism to various degrees and, of course, one of its sources are the writings of Lévi-Strauss. But I would draw your attention to the fact that an awful lot of it actually comes from Dumont, so that we talk about the Dravidian kinship terminology, the opposition between kin and affine, prescriptive two-line terminologies etc. This generic structuralism also comes from the Année Sociologique tradition of Durkheim, Hertz, and Van Gennep. And of course, finally, it comes, last but not least, from the Amerindians themselves.

The second point I want to make is that, in Britain, Lévi-Strauss' thought has typically been mediated by others. Initially the mediation was by Rodney Needham and Leach, both of them Asianists who worked in societies with crosscousin marriage, so at least they vaguely understood what Lévi-Strauss was about. It has then been mediated by the Amazonianist canon itself, and more latterly by Marilyn Strathern. Yes I do mean Marilyn Strathern: I think that The gender of the gift (1988) is a remarkably Lévi-Straussian project. And, most recently, it has been mediated by Eduardo Viveiros de Castro. Now what I mean by direct influence is sustained, sympathetic, well-informed engagement and I would argue that there has been relatively little of this. Why? Well I think the answer is because key features of Lévi-Strauss' conception of anthropology are at odds with the standard British view. On the one hand, this lack of fit has led to neglect and, on the other hand, to misunderstandings. I want to illustrate this point by a few case studies. I cannot cover everything so if you're present and get mentioned, or absent and get left out of this talk, please forgive me.

Before my case studies I want to start with another personal anecdote, apart from Alfred Gell and myself sitting in Leach's lectures in the $60^{\prime} \mathrm{s}$. I first went to Amazonia in 1963 with a copy of Tristes Tropiques (1955) and La Pensée sauvage (1962) in my pocket. I began my undergraduate studies in Cambridge in 1964, when Peter Rivière began his fieldwork. I ended my undergraduate years in 1967, the year of publication of Maybury-Lewis' Akwe Shavante society. My fieldwork began in 1968, the year before Peter Rivière's Marriage among the Trio, and I came back from the field in 1971, just when the last volume of Mythologiques was published and English translations of the previous ones were available. So my early life as an anthropologist was very much influenced by, and all about, this generation of early British Americanists, themselves in various ways influenced or not influenced by Lévi-Strauss.

When I graduated, I announced to the staff at Cambridge that I wanted to go and study in Amazonia. Soon after this, Meyer Fortes called me to his study - Meyer used to speak like this « k-k-k » [speaker imitates click sounds; laughter from the audience]. He said to me "Now Stephen, k-k, I..., k-k..., This is ridiculous! " as he showed me a large map of Ghana. The map was covered by a 
grid and had a series of flags on it. « Now you don't want to go to Amazonia. Think of what happened to Francis Huxley » he said rather bafflingly ${ }^{1}$. And he said: " Now look we've got a space here, down to the left, where we haven't had a researcher so far. Why don't you go there? ».

Now I think that this interview with Meyer Fortes might be said to summarize the British tradition. If I can characterize it very quickly it consists of intense fieldwork which gives a functionalist emphasis on the observable social structure of single societies as integrated systems. Now the other night, we heard Joanna Overing ${ }^{2}$ casting doubts on the utility of the notion of society as an analytical concept. But I can tell you that both she and most of my other colleagues keep " society " as their unit of study. The second point is that for my British colleagues, comparison is controlled comparison, the comparison of same or similar things, or what Lévi-Strauss later went on to call « traits ", in variant conditions. Some of you were brought up, like me, on Audrey Richards" "Some types of family structure amongst the Central Bantu » (1950). That's a classic example of this kind of controlled comparison, and anthropology, according to Jack Goody and others, is a branch of comparative sociology. Finally, that kind of British Social Anthropology had no Archaeology, no Linguistics, no Culture, no History, no Evolution, and no Diffusion. These were all topics that where largely excluded from anthropology when I was an undergraduate.

Let us now look at French or Lévi-Strauss' anthropology. Lévi-Strauss is well versed in United States Amerindian ethnography. He has a very broad comparative reference, has done relatively little fieldwork and he doesn't allow the fieldwork to dominate his work. He dealt and deals with Amerindians, which for the British anthropologists of the time were "primitive societies " right off the United Kingdom map of Africa and Asia. He dealt or deals with " passé » topics - things like totemism, comparative mythology... « My God, not the stuff we're doing! » His book, Les Structures élémentaires de la parenté (1947) has an evolutionist tinge. Mythologiques (1964-1971) is explicitly historical and diffusionist. He has a quite different view of comparison. In fact, if you read Mythologiques carefully, you can see that it is a sustained commentary on the futility of the kind of comparison that many British social anthropologists tried to do. His anthropology has different ends, which are, proximally, the Peoples of the Americas and, distally, Human Nature. He rejects utterly in his work the UK's prime unit of study, society or culture, as an illusion. And his writings are very long, written in French, arrive too late and aren't much read [laughs]. I think that this is so- now you may doubt it, but I speak from experience [laughs]. My conclusion would be then that, for Lévi-Strauss, the words " social ", "structure ", " comparison » and " anthropology » itself, mean rather different things from what they mean to many people in the United Kingdom.

I want now to take four case studies. These represent four different generations and cover four of Lévi-Strauss' main themes or works. For the 60 ' s, I want 
to look at Maybury-Lewis but also at Peter Rivière and Joanna Overing, and at their dialogue or debate with The Elementary Structures. For the 70' s, I want to deal briefly, because I'm trying to deal with too much, with my own work and my wife's work, works which relate to the Savage mind and Mythologiques (C. Hugh-Jones 1979; S. Hugh-Jones 1979). Then I want to quickly cover the $80^{\prime}$ s through Peter Gow's work. This deals with Mythologiques and with Lévi-Strauss' writings on history. And finally into the $90^{\prime}$ s, with Gow's student Elizabeth Ewart, who returns to the Elementary Structures and to Lévi-Strauss' writings on dual organization but who also draws on l'Histoire de lynx (1991).

Let's begin with Maybury-Lewis. His book, Akwe Shavante Society appeared in 1967. You might think that it's quite structuralist, and it might indeed be called " structuralist » but the influence of Lévi-Strauss is quite marginal. In fact where there is any influence of Lévi-Strauss it's actually somewhat hostile. MayburyLewis talks about binary oppositions and dual organization, but this comes essentially from his data, not from Lévi-Strauss. The rest of the book is in some senses quite a hostile challenge to Lévi-Strauss, because what Maybury-Lewis is interested in is the relation between what he might call a two-section kinship terminology and how this operates in practice. To put this into the parlance of British social anthropology, this would be the relation between « social structure » and "social organization ». Maybury-Lewis has an empiricist vision of dual organization, which is something that must be visible and concrete in either sociological or cosmological terms. And the Shavante were, he says, close to the ideal type: in other words, they have dualism in their villages, dualism in their kinship, and dualism in their cosmology. This is the kind of structuralism which for me is much more the structuralism of Hertz mediated via Needham than it is the structuralism of Lévi-Strauss ${ }^{3}$. And in fact Maybury-Lewis was Needham's pupil.

Maybury-Lewis has a quarrel with Lévi-Strauss on the issue of dual organization because, as you will remember, Lévi-Strauss had argued that dual organizations had underlying triadic characteristics, a claim that Maybury-Lewis described as an illegitimate manipulation of sociological models. Now this singly British view of social structure actually misses Lévi-Strauss' point - when I come back to Elizabeth Ewart, you will see why and how. But suffice it to say here that, for Maybury-Lewis, social structure is social relations whilst for Lévi-Strauss, structure is logical relations.

You might also think that the Harvard Central Brazil Project, which began in 1962 and aimed to compare Gê-speaking societies, was also inspired by LéviStrauss. But actually, if you look at it, the comparison involved is not really Lévi-Strauss' style of comparison. It's a comparison of the same things (dualism, uxorilocality, etc.) in different settings. It's very remote, in my opinion, from the sort of transformational structuralism that Lévi-Strauss has advocated. So in conclusion we can say that neither Maybury-Lewis, nor the Harvard Central 
Brazil project, were particularly Lévi-Straussian. In fact, I would argue that they are actually poles apart in terms of comparative method and theory ${ }^{4}$.

Let's now turn to Peter Rivière and Joanna Overing. Both of these, in their books, Marriage among the Trio (Rivière 1969) and The Piaroa (Overing 1975), are really dealing with an unresolved problem in the Elementary Structures of kinship. Namely, how to understand marriage systems in endogamous cognatic societies, whereas the Elementary Structures focuses primarily on prescriptive marriage ordered by clans, lineages and moieties. To use Lévi-Strauss' phraseology, thus is the method of classes versus the method of relations. Rivière and Overing are dealing with the method of relations. Rivière engages in a dialogue with Lévi-Strauss on formal types of prescriptive marriage where he argues that sister's daughter marriage is systemic for the Trio, whereas Lévi-Strauss had described it as a privileged union for the Nambikwara. But otherwise, I think that there's a great deal more of Dumont than of Lévi-Strauss in Rivière's book.

If we now turn to the Individual and society in Guiana (1984), this is not structuralist at all. I think I am right in saying that there is not a single reference to Lévi-Strauss throughout the book ${ }^{5}$. What we have is a controlled, regional comparison of invariants, the shortage of women, the shortage of labour, which underlie affinity as a basic political nexus. The social structure discussed is more that of Fortes or Radcliffe-Brown and this structure precedes its variants, whereas for Lévi-Strauss structure is visible only by an examination of variants. Kinship in Individual and society is treated as an autonomous determinant domain with cosmology as a superstructure. And the conclusion of the book is very Leachian, very much like Pul Eliya (1961) and Political systems of Highland Burma (1954) with society as the outcome of individual negotiations.

With Rivière's paper on blowpipes and hair tubes we begin to see something very different because there he talks about the inverse distribution of blowpipes and hair tubes in Northern and Southern Guyana and correlates this with mythic themes. Briefly, we get blowpipes in Northern Guyana, which go together with a mythic theme of oral incontinence and creation from above, whilst in Southern Guyana we get hair tubes and the theme of sexual incontinence and creation from below. Now this is much more in the style of Lévi-Strauss. And it's interesting to see that, without reference to Rivière, Lévi-Strauss later goes on to talk about precisely these themes, about anal and oral continence and sloths and blowpipes, in The Jealous potter (1988 [1985]).

So I think that the conclusion I would draw here is that early Rivère and Overing are not very Lévi-Straussian and that Overing gets progressively less Lévi-Straussian while Rivière gets more so.

Now a brief word or two about myself. I should remind you that one of the things that happened in the $60^{\prime} \mathrm{s}$ was that Leach sent four of his students to Amazonia: Peter Silverwood Cope, Bernard Arcand and two Hugh-Jones - it wasn't just Christine and myself. In one sense Christine and I were sent by Leach 
to look at Lévi-Strauss' work empirically. In other words, part of our project was to take a critical look at Mythologiques using data collected specifically for that purpose in the field. So, in our fieldwork and in our books we focused on familiar themes like space, animals, houses, mythology, etc. And although I cannot go into the details here, Christine's book might be seen as an extended essay on the $L a$ Pensée sauvage - its all about classification. But it is also "classification on a bicycle " - she is not dealing with the relations between static structures, but rather with the relations between dynamic processes or structures in motion. And if my own work is about the very Lévi-Straussian theme of Amerindan mythology, it is also about ritual. And here is the Leachian influence coming back in: I'm dealing with the relation between myth and ritual, and Christine is looking more at layered analogies between processes than at systems of analogous classification. Or; to put this in other words, while I deal with explicit ritual, Christine is dealing with what Lévi-Strauss has called implicit ritual.

In my work I have also pursued various other Lévi-Straussian themes. I've dealt with the relation between history and myth, and here, like Gow, I have been at pains to reject vulgar criticisms of Lévi-Strauss' contrast between " hot » and " cold " societies. And I've worked on houses and house societies in order to rethink Northwest Amazonian descent. So Lévi-Strauss has been a fundamental point of reference in my own work, but not without some criticism. I have a different view from him on ritual (which I can't go into now) and in my work on houses I have tried to put the architecture back into house societies. But I see my wider project as pursuing an interesting remark about Jurupari myths made by Lévi-Strauss in his Du miel aux cendres. Lévi-Strauss sees these myths as the traces of a complex Middle Amazonian Civilization. As they are quite different from the myths from other parts of Amazonia, he doesn't deal with Jurupari myths very much in his Mythologiques. What I would like to do before I die is to produce an ethnography of the Vaupès and Northwest Amazonia as a regional system, and then to use this to critique other people's attempts to produce syntheses of Amazonia. Seen from the Middle or the Northwest, Amazonia looks quite different. But I'm running fairly short of time so I must keep going and turn to Peter Gow.

Gow's two books are both a consistently Lévi-Strauss inspired project. The project is the integration of ethnography with history, history being understood here as history presented and understood in a specifically Piro manner. His first book (1991) is the ethnographic pole of this project, the role of White People, civilization, goods, etc. in the Piro's reconstruction of themselves as a postMission or post-rubber gathering society. His second book, An Amazonian myth and its history (2001), is the historical pole of this exercise. Here myth itself is a narrative form of history. Gow treats Piro myths as a transformational set and shows how these transformations operate over a relatively short time scale. But he also takes on board something which many of my colleagues have missed, which 
is what Lévi-Strauss has to say about myth-telling as both the interface between structure and event, between myth and personal experience or memory, and as the motor of mythic transformation itself. The influence of Lévi-Strauss is clear. Gow has read and understood Lévi-Strauss and is rightly scathing of those who criticise his distinction between hot and cold societies without understanding what this distinction does and does not imply.

And finally to Elizabeth Ewart (2000) who returns once again to the theme of dual organization. Whereas Maybury-Lewis' vision of dual organisation comes from a Hertzian or Needhamesque vision of diametric dualism, Ewart clearly understands why Lévi-Strauss should insist that there are triadic features within systems of concentric dualism and that such systems are inherently unstable. Maybury-Lewis has a dyadic view of dualism - one side is opposed to the other whereas Lévi-Strauss and Ewart are saying: if you oppose the middle of the village to the periphery, that's dual, but of course there is always a third term, the outside. Thus Maybury-Lewis (1960, p. 39) states that « The surrounds are no more pertinent in the sociological analysis of a "concentric society" than they are in that of a "diametric society" " whilst Lévi-Strauss insists the system is not self-sufficient and that its frame of reference is always the environment ${ }^{6}$.

What Elisabeth Ewart does is to historicise Lévi-Strauss' discussion of dual organisation. For Lévi-Strauss, structure is a set of logical possibilities that are lived out in different forms in different societies. But what Elisabeth Ewart is saying is that there are also a set of logical possibilities that may be lived out in the same society at different moments of time. Briefly what she is saying is that, in Panara society, you have an opposition between panara or " us " and hipe " enemies/others/whites ", one manifestation of which is the opposition between centre and periphery, but another manifestation of which are the two moiety houses within the centre. What she shows is that, as the Panara experience different kinds of outsiders and as their relations with them change, so also does the system change. As White People become more and more dominant in Panara experience, the moiety system declines and the pertinent opposition, the pertinent frame of reference, is now the opposition between panara as Indians as opposed to hipe as White people. Thus thinking in terms of concentric opposition remains constant, but the terms of the opposition between panara and hipe (self/other) are transformed over time.

Elisabeth Ewart's thesis could thus be read as a synthesis of Lévi-Strauss' Elementary Structures of kinship, plus his work on dual organisation, plus his Histoire de lynx. It is also an extended illustration of something that Lévi-Strauss once wrote in Tristes Tropiques when he said: « a sociologist must always bear in mind that primitive institutions are not only capable of conserving what exists but also of elaborating audacious innovations, even though traditional structures are thus profoundly transformed ». What Elisabeth's work is doing is showing us one such audacious transformation. 
My conclusion then is that, in the 60' s, research in Amazonia from Britain bore all the hallmarks of the functionalist divisions between kinship, economics, politics, and religion. What has happened since then is that British Americanists, and all other Americanists I think, have, with good wisdom, progressively abandoned these divisions. If you compare Maybury-Lewis' take on dual organisations with Elisabeth Ewart's take on dual organisations, you will see what I mean. Or if you compare Marriage amongst the Trio with Rivière's recent work you will see it again. Or if you look at Viveiros de Castro's early attempts to synthesise the dravidianate (1993) with his recent work on affinity (2001), or if you compare this recent work to the rather crude « alliance theory » of the seventies, you will again see what I mean.

But, that said, most UK structuralist americanists still have a pretty strong functionalist tendency. They mostly do synchronic fieldwork studies; they tend to have an atomistic focus on single societies; and they tend to assume that these societies remained relatively stable until White people came along. All of this is rather different from the scope and ambitions of Lévi-Strauss' diachronic, dynamic, transformational structuralism. Their take on comparison is also still fairly " functionalist ». Thus Joanna Overing and Allan Passes' The Anthropology of love and anger (2000) is "functionalist 》 in this sense - it looks at the same " thing », here conviviality, in a variety of different ethnographic contexts. All of this is very different from Lévi-Strauss on myth, from Viveiros de Castro on affinity and perspectivism (1996), or from Descola (2005) on systems of thought. All of these are " structuralist » in a very different sense from much of the UK tradition. And even those who have been most influenced by Lévi-Strauss, like myself, Christine Hugh-Jones, Gow, and Ewart, still tend to merge their structuralism with a UK tradition based on intensive ethnographic fieldwork. We apply Lévi-Strauss' insights on classification, history and myth to our fieldwork data, and we use our fieldwork data to refine the Lévi-Straussian project, but we still tend to be monographic and single-society in our approaches. This is both a strength and a weakness.

At their worst, British anthropologists can be downright hostile to structuralism. Here we have Allan Campbell (1995) who writes « never mind the structuralism, that was an intellectually frivolous fad of the $60^{\prime} \mathrm{s}$ and $70^{\prime} \mathrm{s}$ ». He's talking about beer feasts and the implication is: "Let's get on and find out what the Wayampi think about drinking. Real anthropology is about what the people think, not what the anthropologist thinks ». Now this kind of approach with its emphasis on single societies and views from the inside was necessary in the early years because in those days there was very little data. But it is much less necessary today. Amazonia and South America are no longer the least known continent ${ }^{7}$, and Amazonia is at last taking its place in mainstream anthropological theory. In addition, Amazonian anthropology has been historicised, partly by archaeology and partly through archival research, in ways that Lévi-Strauss may not have 
thought possible. We now have enough historically contextualised ethnographic data and refined theoretic outlook to return to Lévi-Strauss' much bigger project, and that's what I think my colleagues and I in Britain should be doing, indeed what I think we should all be doing. This bigger project concerns the nature of Amazonian and Amerindian civilisation as a whole, a project that Lévi-Strauss summed up when he characterised Amazonia as « a Middle Ages without a Rome ". I think that this is the project we should now be working on. Thank you.

\section{NOTES}

1. Francis Huxley, whose best-selling book on the Urubu Indians was initially published in 1956, was a Research Fellow of St Catherine's College, Oxford, for five years, then pursued his career as a Senior Lecturer at City University, London. He now lives in Santa Fe and in the past decades, has devoted most of his professional interest to the study of psychotropic substances. However, Fortes considered he never really became a professional academic anthropologist, never wrote a " proper " monograph, and dabbled with dodgy subjects like voodoo, drugs, etc.

2. The day before this Parisian conference was recorded, Joanna Overing had given a keynote speech after the conference dinner at St Anne's College, Oxford, as guest speaker of SALSA's fifth Sesquiannual meeting.

3. See Needham (ed.) 1973.

4. Results of the Harvard Central Brazil project can be found in Maybury-Lewis (ed.) 1979.

5. Actually, Peter Rivière does mention Lévi-Strauss in his book, but only four times, and rather briefly.

6. This of course is somewhat reminiscent of the controversy, also relating to Gê peoples (namely the Kayapo), between Oxford's Vanessa Lea and Harvard's Terence Turner.

7. Allusion to Patricia Lyon's classic reader published in 1974, whose subtitle refers to South America as « the least known continent ».

\section{REFERENCES}

CAmpbell Allan Tormaid

1995 Getting to know Waiwai. An Amazonian ethmography, Routledge, New York.

Descola Philippe

2005 Par-delà la nature et la culture, Gallimard, Bibliothèque des sciences humaines, Paris.

\section{Ewart Elisabeth}

2000 Living with each other: selves and alters amongst the Panará of central Brazil, Ph.D. dissertation, London School of Economics.

Gow Peter

1991

Of mixed blood: kinship and history in Peruvian Amazonia, Clarendon Press, Oxford. 
Hugh-JoNes Christine

1979 From the Milk River: spatial and temporal processes in Northwest Amazonia, Cambridge University Press, Cambridge.

Hugh-JoNes Stephen

1979 The Palm and the Pleiades. Initiation and cosmology in Northwest Amazonia, Cambridge University Press, Cambridge.

HuXLey Francis

1956 Affable savages, Capricorn books, New York.

LEACH Edmund

1954 Political systems of Highland Burma. A study of Kachin social organization, G. Bell and sons, London.

1961 Pul Eliya, a village in Ceylon: a study of land tenure and kinship, Cambridge University Press, Cambridge.

\section{Lévi-Strauss Claude}

1947 Les Structures élémentaires de la parenté, Mouton and C ${ }^{\circ}$, Paris/La Haye.

1955 Tristes Tropiques, Plon, Paris.

1962 La Pensée sauvage, Plon, Paris.

1966-1971 Mythologiques I-V, Plon, Paris [English translation by John Weightman and Doreen Weightman].

1964 Mythologiques I. Le Cru et le cuit [The raw and the cooked, 1969].

1966 Mythologiques II. Du miel aux cendres [From honey to ashes, 1973].

1968 Mythologiques III. L'Origine des manières de table [The origin of table manners, 1978].

$1971 \quad$ Mythologiques IV. L'Homme nu [The naked man, 1981].

1985 La Potière jalouse, Plon, Paris [English translation: 1988, The Jealous potter, London/Chicago, The University of Chicago Press].

1991 Histoire de lynx, Plon, Paris.

Lyon Patricia J. (ed.)

1974 Native South Americans. Ethnology of the least known continent, Little Brown and Company, Boston.

MAYbury-Leivis David

1960 "The analysis of dual organizations : a methodological critique », Bijdragen: Tot de Taal-, Land-en Volkenkunde, 116, pp. 2-43.

1967 Akwe Shavante society, Clarendon Press, Oxford.

MAYbury-Lewis David (ed.)

1979 Dialectical societies. The Gê and Bororo of Central Brazil, Harvard University Press, Cambridge/London.

NeEDham Rodney (ed.)

1973 Right and left: essays on dual symbolic classification, foreword by E. E. Evans-Pritchard, The University of Chicago Press, Chicago/London. 
OVERING KaPLAN Joanna

1975 The Piaroa. A people of the Orinoco Basin. A study in kinship and marriage, Clarendon Press, Oxford.

Overing Joanna and Allan PASSES (eds)

2000 The Anthropology of love and anger, Routledge, London.

Richards Audrey

1950 "Some types of family structure amongst the Central Bantu », in Alfred R. Radcliffe-Brown and Daryll C. Forde (eds), African systems of kinship and marriage, Oxford University Press, London, pp. 207-251.

RiviÈRe Peter G.

1969 Marriage among the Trio, Clarendon Press, Oxford.

1984 Individual and society in Guiana. A comparative study of Amerindian social organization, Cambridge Studies in Social Anthropology, Cambridge.

STRATHERn Marilyn

1988 The gender of the gift. Problems with women and problems with society in Melanesia, University of California Press, Berkeley/Los Angeles.

Viveiros de CASTRo Eduardo

1993 "Alguns aspectos da afinidade no dravidianato Amazônico ", in Eduardo Viveiros de Castro and Manuela Carneiro da Cunha (eds), Amazônia:

etnologia e historia indigena, USP/FAPESP, São Paulo, pp. 150-210.

1996 "Os pronomes cosmológicos e o perspectivismo Ameríndio », Mana, 2 (2), pp. 115-144 [English translation: 1998, Cosmological deixis and Amerindian perspectivism, Journal of the Royal Anthropological Institute,

2001 "GUT feelings about Amazonia: potential affinity and the construction of sociality ", in Laura Rival and Niels Whitehead (eds), Beyond the visible and the material: the amerindianization of society in the work of Peter Rivière, Oxford University Press, Oxford, pp. 19-43. 